\title{
Treatment of leukemia antigen-loss relapses occurring after CD19-targeted immunotherapies by combination of anti-CD123 and anti-CD19 chimeric antigen receptor $\mathrm{T}$ cells
}

\author{
Marco Ruella ${ }^{1 *}$, David M Barrett ${ }^{2}$, Saad S Kenderian ${ }^{1}$, Olga Shestova ${ }^{1}$, Ted J Hofmann², John Scholler ${ }^{1}$, \\ Simon F Lacey', Jan J Melenhorst ${ }^{1}$, Farzana Nazimuddin' ${ }^{1}$, Jessica Perazzelli², David A Christian³, \\ Christopher A Hunter ${ }^{3}$, David L Porter ${ }^{4}$, Carl H June ${ }^{1}$, Stephan A Grupp ${ }^{2}$, Saar Gill ${ }^{1}$
}

From 30th Annual Meeting and Associated Programs of the Society for Immunotherapy of Cancer (SITC 2015) National Harbor, MD, USA. 4-8 November 2015

\section{Introduction}

Anti-CD19 chimeric antigen receptor T cells (CART19) and bi-specific anti-CD19/CD3 antibodies (blinatumo$\mathrm{mab}$ ) are generating unprecedented complete responses in relapsing/refractory B-cell acute lymphoblastic leukemia ( $r / r$ B-ALL). However, a subset of patients still relapse and about $30-50 \%$ of these relapses are characterized by the loss of detectable CD19 [1-3]. The interleukin-3 receptor alpha, or CD123, was shown to be expressed in several hematologic neoplasms, including acute myeloid leukemia and more recently also B-ALL. The goal of this study was to pre-clinically evaluate the impact of targeting both CD19 and CD123 with chimeric antigen receptor $\mathrm{T}$ cells for the treatment and prevention of CD19-negative relapses occurring after CD19-directed therapies $[4,5]$.

\section{Results}

CD123 expression was analyzed by flow cytometry in 36 r/r B-ALL samples: CD123 was highly expressed (81.75\%, range: $5.10-99.60)$, representing a promising candidate for targeted therapy in B-ALL. Moreover, CD123 was also found to be expressed in the putative leukemia stem cells, identified as CD34-pos CD38-neg. The expression of CD123 was detected in all $(n=6)$ CD19-negative B-ALL blasts analyzed after relapse from CART19 treatment (representative case in Figure 1).
Therefore, we generated anti-CD123 chimeric antigen receptor $\mathrm{T}$ cells co-stimulated with 4-1-BB using a lentiviral vector (CART123) [5]. We then evaluated the CART123 anti-leukemia efficacy both in vitro and in vivo against primary B-ALL blasts and the cell line NALM-6. CART123 showed intense anti-leukemia activity, as defined by specific CD107a degranulation, cytokine production, cytotoxicity and proliferation, not statistically different from that of CART19. In order to test the role of CART123 to target CD19- negative relapses we developed a novel in vivo model, engrafting immunodeficient NSG mice with blasts from a patient relapsing with CD19-negative disease after CART19 treatment. At day 14 mice were randomized to receive control $\mathrm{T}$ cells (UTD), CART19, or CART123 in combination with CART19. CART19 and control T cell treated mice showed no anti-tumor activity, while CART123+CART19 led to complete eradication of the disease and long-term survival (Figure 2).

\section{Conclusions}

Here we demonstrate that CD123 is expressed in CD19negative B-ALL relapses occurring after CD19-directed therapies, and that combining CART123 cells with CART19 cells is an effective therapy for the treatment and prevention of antigen-loss relapses in B-ALL murine xenografts. 

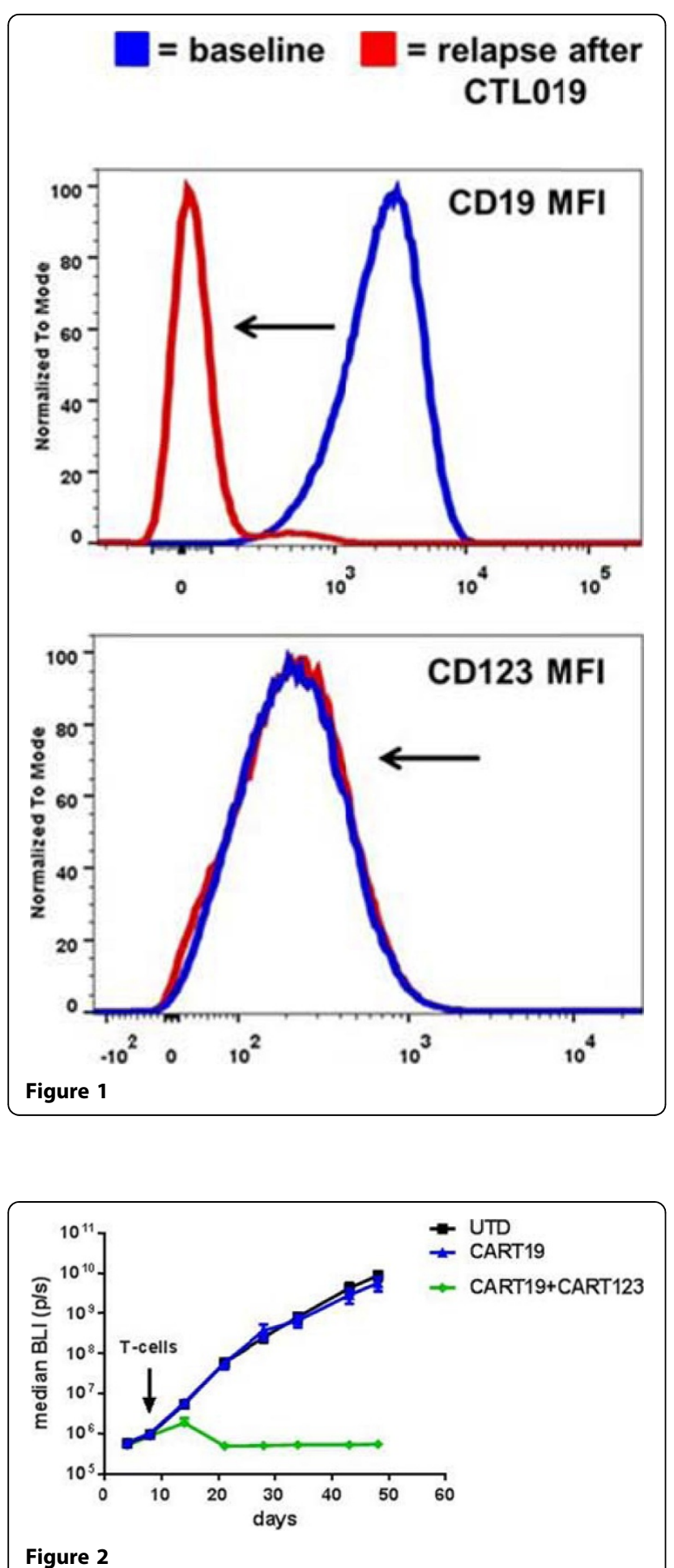

\section{Acknowledgments}

This work was supported by: the 2014 SITC-EMD Serono Cancer Immunotherapy Clinical Fellowship Award and the Gabrielle's Angel Foundation (PI: Marco Ruella); the University of Pennsylvania-Novartis Research Alliance (PI: Carl H. June).

\section{Authors' details}

'Center for Cellular Immunotherapies, Perelman School of Medicine at the University of Pennsylvania, Philadelphia, PA, USA. ${ }^{2}$ Department of Pediatrics, Perelman School of Medicine at the University of Pennsylvania, Philadelphia, PA, USA. ${ }^{3}$ Department of Pathobiology, School of Veterinary Medicine at the University of Pennsylvania, Philadelphia, PA, USA. ${ }^{4}$ Division of HematologyOncology, Department of Medicine, Perelman School of Medicine at the University of Pennsylvania, Philadelphia, PA, USA.

Published: 4 November 2015

\section{References}

1. Maude SL, Frey N, Shaw PA, Aplenc R, Barrett DM, Bunin NJ, et al: Chimeric antigen receptor $\mathrm{T}$ cells for sustained remissions in leukemia. $\mathrm{N}$ Engl J Med 2014, 371(16):1507-1517.

2. Davila ML, Riviere I, Wang X, Bartido S, Park J, Curran K, et al: Efficacy and Toxicity Management of 19-28z CAR T Cell Therapy in B Cell Acute Lymphoblastic Leukemia. Sci Transl Med 2014, 6(224):224ra25.

3. Topp MS, Gokbuget N, Stein AS, Zugmaier G, O'Brien S, Bargou RC, et al: Safety and activity of blinatumomab for adult patients with relapsed or refractory B-precursor acute lymphoblastic leukaemia: a multicentre, single-arm, phase 2 study. Lancet Oncol 2015, 16(1):57-66.

4. Liu K, Zhu M, Huang Y, Wei S, Xie J, Xiao Y: CD123 and its potential clinical application in leukemias. Life Sci 2015, 122:59-64.

5. Gill S, Tasian SK, Ruella M, Shestova O, Li Y, Porter DL, et al: Preclinical targeting of human acute myeloid leukemia and myeloablation using chimeric antigen receptor-modified T cells. Blood 2014, 123(15):2343-2554.

doi:10.1186/2051-1426-3-S2-05

Cite this article as: Ruella et al:: Treatment of leukemia antigen-loss relapses occurring after CD19-targeted immunotherapies by combination of anti-CD123 and anti-CD19 chimeric antigen receptor T cells. Journal for ImmunoTherapy of Cancer 2015 3(Suppl 2):05.

\section{Submit your next manuscript to BioMed Central} and take full advantage of:

- Convenient online submission

- Thorough peer review

- No space constraints or color figure charges

- Immediate publication on acceptance

- Inclusion in PubMed, CAS, Scopus and Google Scholar

- Research which is freely available for redistribution 